\title{
THE GREENING FOR MANAGEMENT SECURITY OF AGRIBUSINESS CORPORATION
}

\author{
Oleksandra Liashenko ${ }^{1}$, Ruslan Markov ${ }^{2}$ \\ ${ }^{1}$ Doctor of Science (Economics), Professor, KROK University, Kyiv, Ukraine, e-mail: lom@krok.edu.ua, \\ ORCID: https://orcid.org/0000-0001-7114-4501 \\ Ph.D. (economics), doctoral student, KROK University, Kyiv, Ukraine, e-mail.: markov_r@ukr.net, ORCID: \\ https://orcid.org/0000-0002-8150-8249
}

Food systems around the world are changing. Urbanization and income growth are changing food demand, visible in increased demand for vegetables, fruits, meats, and dairy products, as well as for processed foods. As the production of all these food items is more resource-intensive, the change in dietary preferences is increasing pressures on already scarce and depleted natural resources. Urbanization also requires food to be easily stored and transported. Thus, large-scale distribution and food processing have become increasingly important as drivers of the transformation of food systems. This transformation has brought about many improvements in food safety and food availability, but it has also resulted in the standardization of agricultural output and, in many cases, the concentration of primary production and the consolidation of farmland. Many smallholder farmers have become landless agricultural workers or have migrated to towns and cities in search of employment, thus accelerating urbanization further.

In many countries, there is a new powerful threat - agro-terrorism, which causes large-scale disruptions due to loss of livelihood, income, and production. Agribusiness protection can also be problematic due to the lack of stability and basic biosecurity infrastructure for the detection and prevention of diseases or invasive species. There is currently evidence of common terrorist threats, agricultural vulnerabilities and, depending on the country, the potentially serious consequences of slang terrorism. Where specific threats arise, the international community may need to strengthen biosecurity systems in developing countries by, for example, increasing global cooperation.

Nowadays there are many factors that determine the special attitude to agribusiness around the world and in Ukraine: global climate change, abrupt geoeconomic change, disasters, and eventually pandemics like Covid-19.

Agribusiness around the world has suffered from the COVID-19 pandemic, albeit less than other businesses, but at the same time intoxicating the pandemic can bring significant economic dividends, quickly create and protect millions of jobs for vulnerable populations and provide rapid and lasting health benefits. I and the environment for citizens, while contributing to economic and security of agribusiness. However, a tool for such acceleration is needed. It can be greening.

The global content of greening as a security activity is to eliminate the contradictions between environmental and economic systems to combat environmental threats and ensure economic security.

World has changed during the past 50 years, so has agriculture. And so has agricultural research, which continues to confront new challenges, from food security 
to ecological concerns to land use issues. For example, agricultural land under agrienvironmental measures as a share of the country's UAA (Fig. 1).

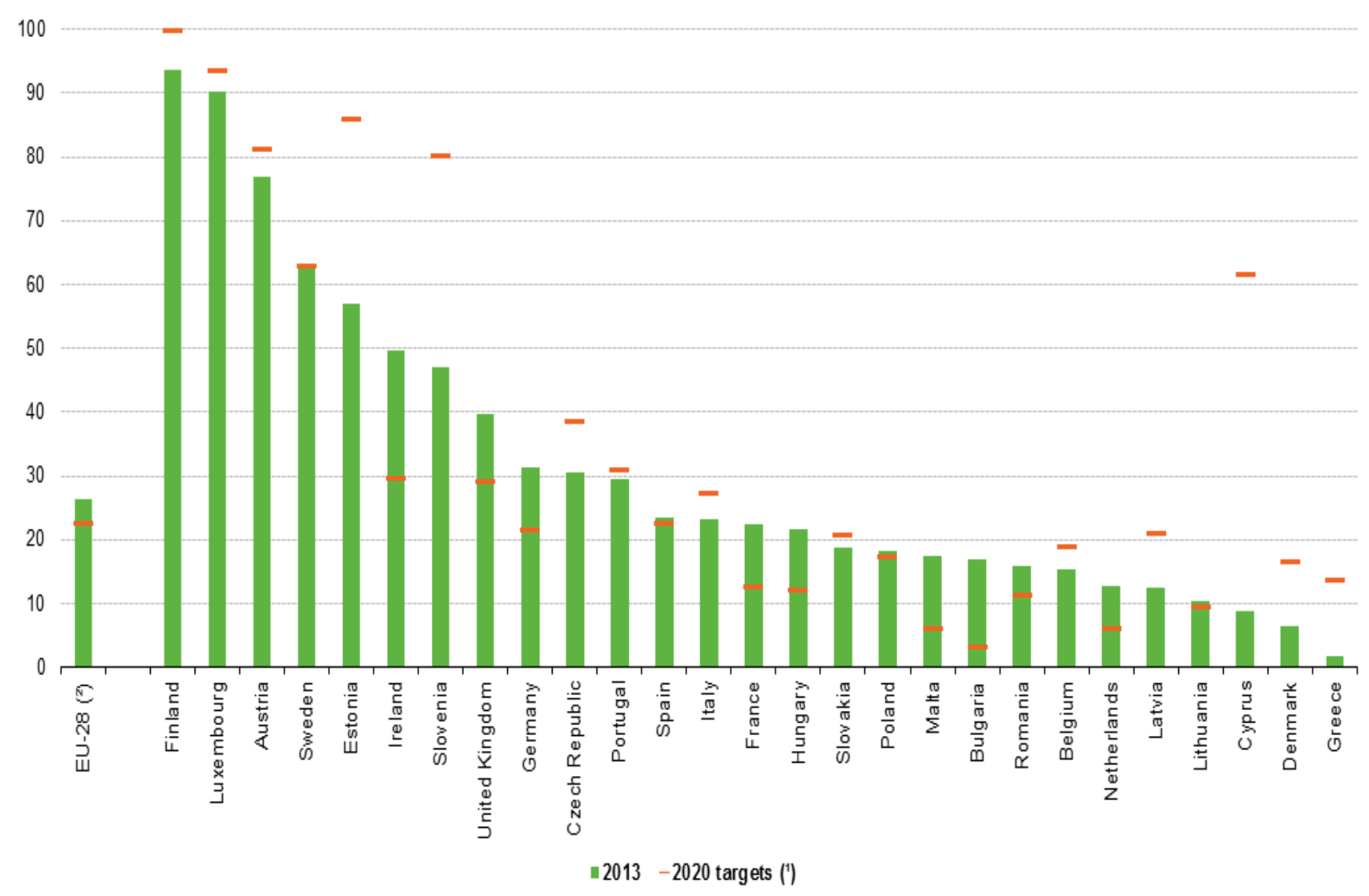

(') Targets for 2020 in percentage is based on Eurostat estimates of utilised agricultural area in 2020. $\left({ }^{2}\right)$ EU-28 excluding Croatia for 2013.

Sources: DG Agriculture and Rural Development (RDIS2 12 June 2017); Eurostat for utilised agricultural area (online data code: apro_acs_a) Rural Development Information System - Indicator Database Information Monitoring (RDIS IDIM)

European Network for Rural Development (ENRD) website: http:/lenrd.ec.europa.eu/en/home-page_en.cfm

\section{Fig. 1. Agricultural land under agri-environmental measures as a share of the country's UAA, 2013 and targets for $2020(\%)$.png}

Source: [1]

At the same time, when we talk about Ukraine, the pressure of mineral fertilizers on arable land has only increased, although the area under this "pressure" has hardly increased (Table 1).

Food chains are also becoming longer - with a greater ecological footprint - and there are increasing concerns over the quality of ultra-processed food and its association with overweight and obesity. These changes are taking place in different ways and at different speeds across regions and countries. Common features, however, include a shrinking share of agricultural production and employment in the economy, changing food consumption patterns, and a shift from subsistence to more commercial farming. 
Table 1. Adding mineral and organic fertilizers in Ukraine

\begin{tabular}{|c|c|c|c|c|c|c|c|c|c|c|c|c|c|c|c|c|c|c|c|c|c|}
\hline 1990 & 1996 & 2000 & 2001 & 2002 & 2003 & 2004 & 2005 & 2006 & 2007 & 2008 & 2009 & 2010 & 2011 & 2012 & 2013 & 2014 & 2015 & 2016 & 2017 & 2018 & 2019 \\
\hline \multicolumn{22}{|c|}{ The arable land in the country, mln.ha } \\
\hline 42,0 & 41,8 & 41,8 & 41,8 & 41,8 & 41,8 & 41,8 & 41,8 & 41,7 & 41,7 & 41,7 & 41,6 & 41,6 & 41,6 & 41,6 & 41,5 & 41,5 & 41,5 & 41,5 & 41,5 & 41,5 & 41,5 \\
\hline \multicolumn{22}{|c|}{ Areas treated with mineral fertilizers, mln.ha } \\
\hline 26,4 & 8,2 & 4,7 & 6,4 & 6,3 & 5,8 & 7,9 & 7,8 & 9,6 & 11,0 & 12,9 & 11,5 & 12,7 & 14,2 & 14,6 & 15,4 & 14,8 & 14,5 & 15,7 & 16,5 & 16,1 & 16,4 \\
\hline \multicolumn{22}{|c|}{ The proportion of the area treated with chemical fertilizers, the total area of agricultural land, $\%$} \\
\hline 62,9 & 19,6 & 11,2 & 15,3 & 15,1 & 13,9 & 18,9 & 18,7 & 23,0 & 26,4 & 30,9 & 27,6 & 30,5 & 34,1 & 35,1 & 37,1 & 35,7 & 34,9 & 37,8 & 39,8 & 38,8 & 39,5 \\
\hline \multicolumn{22}{|c|}{ Adding organic fertilizer, 1,000 tons } \\
\hline 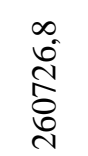 & $\begin{array}{l}\text { N } \\
\underset{0}{0} \\
\stackrel{\infty}{\infty}\end{array}$ & 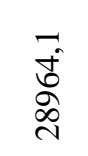 & 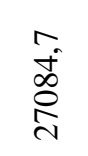 & $\frac{N}{\stackrel{d}{d}}$ & $\begin{array}{l}0 \\
\stackrel{2}{N} \\
\stackrel{=}{=}\end{array}$ & $\begin{array}{l}\vec{\infty} \\
\infty \\
\infty \\
n \\
N\end{array}$ & $\begin{array}{l}m \\
\infty \\
\infty \\
m\end{array}$ & $\begin{array}{l}\stackrel{2}{\sigma} \\
\frac{\sigma}{-}\end{array}$ & 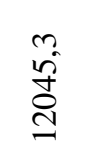 & $\begin{array}{l}\overrightarrow{2} \\
\hat{2} \\
0\end{array}$ & $\frac{\vec{n}}{\tilde{n}}$ & 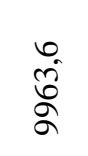 & $\begin{array}{l}\stackrel{\gamma}{\sigma} \\
\stackrel{\sim}{\alpha}\end{array}$ & $\begin{array}{l}r \\
n \\
\infty \\
0 \\
0\end{array}$ & $\begin{array}{l}\hat{a} \\
\hat{2} \\
0\end{array}$ & $\begin{array}{l}\nabla_{0} \\
\infty \\
\infty \\
\infty\end{array}$ & 중 & $\begin{array}{l}\hat{a} \\
\hat{\sigma} \\
\frac{a}{a}\end{array}$ & $\frac{\hat{\Omega}}{\hat{~}}$ & \begin{tabular}{l}
0 \\
o \\
\multirow{0}{0}{} \\
$=$
\end{tabular} & $\begin{array}{l}n \\
\text { ñ } \\
\infty \\
\cong \\
=\end{array}$ \\
\hline \multicolumn{22}{|c|}{ Adding of organic fertilizers per 1 area of agricultural land, $\mathrm{kg} /$ ha } \\
\hline 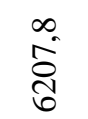 & $\vec{J}$ & $\hat{\widehat{d}}$ & \begin{tabular}{l}
0 \\
$\infty$ \\
\multirow{0}{*}{}
\end{tabular} & $\begin{array}{l}\hat{i} \\
\hat{n}\end{array}$ & 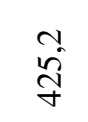 & $\hat{n}$ & 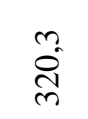 & $\begin{array}{l}\infty \\
\frac{n}{m}\end{array}$ & $\begin{array}{l}\stackrel{a}{ } \\
\infty \\
\infty \\
\infty\end{array}$ & $\hat{\sim}$ & î & 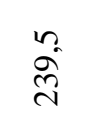 & ڤે & $\begin{array}{l}\infty \\
\text { d } \\
\tilde{N}\end{array}$ & $\begin{array}{l}0 \\
\text { i } \\
\text { ते }\end{array}$ & $\begin{array}{l}n \\
\infty \\
\infty \\
\end{array}$ & $\begin{array}{l}\infty \\
\text { त } \\
\text { ते }\end{array}$ & 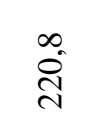 & $\stackrel{n}{\stackrel{n}{2}}$ & $\stackrel{\curvearrowright}{\circ}$ & 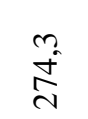 \\
\hline \multicolumn{22}{|c|}{ Areas treated with organic fertilizers, million hectares } \\
\hline 5,5 & 1,9 & 0,7 & 0,7 & 0,7 & 0,6 & 0,5 & 0,5 & 0,5 & 0,5 & 0,5 & 0,5 & 0,4 & 0,4 & 0,4 & 0,4 & 0,4 & 0,4 & 0,5 & 0,5 & 0,8 & 0,8 \\
\hline \multicolumn{22}{|c|}{ The proportion of the area treated with organic fertilizers, the total area of agricultural land $\%$} \\
\hline 13,1 & 4,5 & 1,7 & 1,7 & 1,7 & 1,4 & 1,2 & 1,2 & 1,2 & 1,2 & 1,2 & 1,2 & 1,0 & 1,0 & 1,0 & 1,0 & 1,0 & 1,0 & 1,2 & 1,2 & 1,9 & 1,9 \\
\hline
\end{tabular}

Sourse: developed by authors according of the State Statistics Service of Ukraine, http://www.ukrstat.gov.ua 
This is changing the way rural and urban development, poverty, and hunger challenges need to be addressed. The structural transformation of economies, and the food systems within them, can provide an effective way out of poverty and hunger for many. However, this process is not automatic. It tends to be more effective when based on the development of strong linkages between agricultural and nonagricultural sectors and between urban and rural areas. Natural resource constraints and climate change also require the changes to be resource-efficient and environmentally sustainable.

As the COVID-19 pandemic has unfolded, concerns over ensuring food security have been voiced in many countries around the world. While the crisis has immediate effects on food and agricultural supply chains, the negative impact of the COVID-19 pandemic is not limited to short-term disruptions in supply and demand. Considering that the food and agricultural sector accounts for ten percent of global GDP and employs an estimated 1.5 billion people worldwide, the outbreak of COVID-19 will likely have far- reaching and noticeable social and economic consequences for the sector. Investing as part of COVID-19 recovery packages can help national governments create much needed economic security and jobs today, whilst making rapid strides towards a resilient and inclusive future.

From the first half of the twentieth century due to the aggravation of environmental problems, there is an integration of ecology and economy. There are various approaches and grounds for such integration, including neoclassical and ecological reductionism.

"Greening" of the economy occurs within the methods and approaches of environmental and environmental economies. The summit in Rio de Janeiro in 1992 proposed a concept of sustainable development, which combined the interests of environmental protection and economic development. In the context of these events, the environmental economy emerged, which created a new methodological platform for scientists specializing in various fields, which includes representatives of schools of environmental and environmental economics, whose theoretical foundations and practical approaches need further development.

Thus, the environmental economy is:

- a branch of neoclassical economics that studies such environmental problems, such as pollution, negative externalities (externalities) and assessment of non-market values of the environment;

- a concept that seeks to find the cause of environmental problems and propose a policy of preventing them from an economic point of view.

- associated with the efficient allocation of environmental resources and determines the interdependence of the environment and the economy. 
Basic methodological approaches used in the research of environmental economists: stability, the value of natural resources, interdisciplinary.

Basic approaches to "environmental economics":

1. Environmental problems, including environmental, are considered as part of the problems of the economic system.

2. Natural capital may be replaced by human capital and / or man-made capital.

3. Lack of resources can be overcome by additional costs in the economy.

4. Pollution is considered as market externalities, respectively, related problems are solved using market mechanisms.

5. Technology is seen as a way to solve problems

environment and a mechanism to increase the efficiency of the economy.

6. The degree of human impact on the environment depends on the use of innovation, resource efficiency, human capital, technological level of economic development.

The conceptual framework is inspired by an ecosystem approach. While the level of detail of properties and relevant indicators, the communication ability, and the way in which the framework is applied can be criticized and re-adjusted, we believe that this framework can support proactive assessments of food systems under an ecosystem approach perspective [2-12].

The term "greening" is used to denote activities which improves the protection, use and reproduction of resources, is:

- greening of science;

- greening of education;

- greening of public;

- relations;

- greening of nature;

- greening of production;

- industry;

- economic activity;

- economic systems, economy;

- social development;

- social development etc.

Rapid population growth and aggregate demand an appropriate level of economic and social development, which, in turn, leads to an increase in the level of destructive impact on the ecological system.

Greening is a socio-economic concept. Greening is also a relationship that arises between different entities at the international, state and local levels and are an integral part of international, economic and socio-political relations, etc. 
Greening can be considered as an activity, primarily practical, aimed at transforming social development into an environmentally safe form, or cognitive activity, which is represented by a number of discoveries and developments in this area. Greening in certain aspects manifests itself as a tool or method, including policy - economic, environmental, state, and so on.

The multi-functionality of the concept of greening is structured by levels:

- global;

- national;

- regional;

- local;

- personal.

Greening manifests itself at different levels, as it is provided by different actors and on different scales.

Greening in the system of economic security is the basis for understanding its role in the security of agribusiness as in broad and narrow sense.

One of the main types of greening is "greening of science and education", which is interpreted as the process of mastering new ideas in economic, environmental, social and spiritual spheres, used in the learning process to train highly educated professionals who will have to resist environmental threats at the global, national, regional, and local levels in all spheres of public activity [14].

The greening of science makes it possible to ensure the formation of a theoretical basis for the penetration of relevant ideas into the education system. The purpose of this process is to overcome environmental threats to the economic security of the state. We believe that the greening of science is the first link in the greening of social development.

Another type of greening is the greening of nature - is the improvement of economic relations in the process of interaction of production with the environment, which are aimed at increasing the level environmental effect per unit of consumer value produced and make it possible to overcome global, national, regional, and local threats. Reducing the nature of products in the long run will overcome both global and local threats to economic security.

There is a concept of greening of production: generation of new scientific ideas and information materials, creation of technical means and technological decisions promoting development of ecologically safe systems.

Greening of production is an expanded reproduction of natural resources by improving technology, organizing material production, increasing labor efficiency in the environmental sphere.

There is also a phrase "greening of social development." Obviously, we need to talk about the greening of sustainable development. 
Table 2. illustrates agro-ecosystems' functional and structural properties and lists some representative indicators that could guide the analysis of the different agriculture, forestry, and fisheries management options. Indicators included under each property are indicative of the type of information to be researched, but reporting is not exhaustive.

\section{Table 2. Agro-ecosystems' functional and structural properties and indicators}

\begin{tabular}{|c|c|c|c|}
\hline \multicolumn{4}{|c|}{ Functional Properties } \\
\hline \multirow{4}{*}{\multicolumn{2}{|c|}{$\begin{array}{l}\text { Efficiency of resource use assessed under } \\
\text { normal conditions in terms of: } \\
\text { Physical yield per unit of input (productivity) } \\
\text { Commercial yield per unit of input } \\
\text { Life quality of producers and consumers }\end{array}$}} & \multirow{4}{*}{\multicolumn{2}{|c|}{$\begin{array}{l}\text { Resilience to environmental and macro-economic } \\
\text { risk assessed under disturbed conditions in terms } \\
\text { of: } \\
\text { Physical yield per unit of input (productivity) } \\
\text { Commercial yield per unit of input } \\
\text { Life quality of producers and consumers }\end{array}$}} \\
\hline & & & \\
\hline & & & \\
\hline & & & \\
\hline \multicolumn{4}{|c|}{ ral Properties } \\
\hline Connectedness Assessed in terms of: & \multirow{4}{*}{\multicolumn{2}{|c|}{$\begin{array}{l}\text { Coherence Assessed in terms of: } \\
\text { Ecological balance (water, soil, } \\
\text { habitat, nutrient, energy) } \\
\text { Economic integration } \\
\text { Household labor }\end{array}$}} & $\begin{array}{l}\text { Diversity Assessed in } \\
\text { terms of: }\end{array}$ \\
\hline & & & \\
\hline & & & \\
\hline & & & \\
\hline
\end{tabular}

Source: [12]

Transitioning to sustainable and resilient production methods Investing in food and agriculture systems is not enough. It will also be important to transition towards types of food production systems that will be less vulnerable to the risks outlined in the previous working paper, as well as more capable of effectively responding to the risks without loss of food security.

This means adopting farming, fishery and forestry systems that are more resilient to climate change and, in particular, extreme weather variability. It means managing land, water, biodiversity and ecosystems in ways that enhance their longterm productivity rather than depleting them - i.e. building natural capital instead of spending it. But it also means reducing the external polluting effects of agriculture, especially in the form of greenhouse gas emissions.

Fig. 2 shows comparison of sustainable development indicators and threats In Ukraine, Germany and China.

Higher values of Sustainable Development Index (Q), Components of Life Quality (Cql) and Security (Csl) and values of Dimensions of Life Quality Component (Ie, Iec, Is) comply with better country development performance. Higher values of threats' indicators (close to 1) and Vulnerability Index (Ivul) correspond to a greater threat manifestation. 

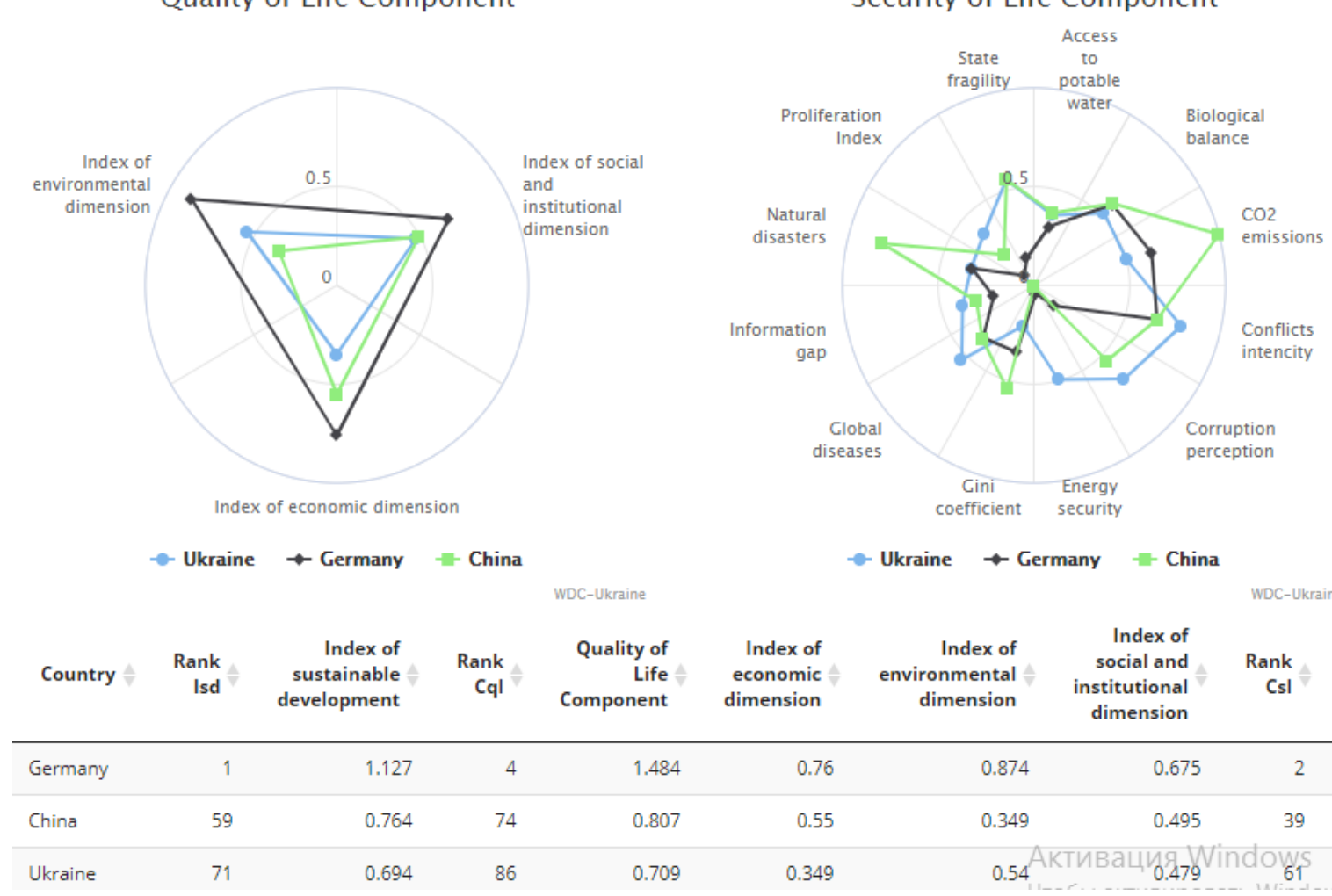

\begin{tabular}{|c|c|c|c|c|}
\hline \multirow[b]{2}{*}{$\begin{array}{l}\text { Index of } \\
\text { economic } \\
\text { dimension }\end{array}$} & \multirow[b]{2}{*}{$\begin{array}{c}\text { Index of } \\
\text { environmental } \\
\text { dimension }\end{array}$} & \multirow[b]{2}{*}{$\begin{array}{r}\text { Index of } \\
\text { social and } \\
\text { institutional } \\
\text { dimension }\end{array}$} & \multicolumn{2}{|c|}{ WDC-Ukraine } \\
\hline & & & $\begin{array}{r}\text { Rank } \\
\text { Csl }\end{array}$ & $\begin{array}{r}\text { Security of } \\
\text { Life }\end{array}$ \\
\hline 0.76 & 0.874 & 0.675 & 2 & 1.677 \\
\hline 0.55 & 0.349 & 0.495 & 39 & 1.385 \\
\hline 0.349 & 0.54 & 0.479 & 61 & 1.283 \\
\hline
\end{tabular}

Fig. 2. Comparison of sustainable development indicators and threats in Ukraine, Germany and China

Source: developed by authors according of Recourse [13]

FAO has identified sustainable crop production intensification (SCPI) as one of its strategic objectives. Ecological intensification has been defined as producing more from the same area of land while reducing negative environmental impacts and increasing contributions to natural capital and the flow of environmental services. To achieve this, FAO has endorsed an "ecosystem approach", which means using inputs such as land, water, seed and fertilizer to complement the natural processes that support plant and animal growth. A range of farming practices and technologies, often location specific, have been developed, drawing on five broad types of practices (FAO, 2011c).

Soil fertility. Building soils with a high content of non-living soil organic matter, a rich diversity of its biota, good physical structure and adequate crop nutrients through a combination of organic nutrient inputs and judicious use of mineral fertilizers.

Farming systems. Implementing agro-ecological approaches that minimize soil disturbance by mechanical tillage, enhance and maintain organic matter cover, and diversify plant species in associations, sequences and rotations, and integrate them with livestock. 
Seeds and breeds. Improving the conservation and use of genetic resources, and developing crops and varieties that are more resilient to climate extremes, pests and diseases, less dependent on external inputs and better adapted to ecologically based production practices. Utilizing publicly funded research, local seed and breed delivery systems and the private sector to disseminate new or improved varieties to farmers.

Water management. Increasing soil moisture conservation in rain fed systems by building soil health, expanding use of water harvesting and retention structures on farms, rehabilitating and constructing irrigation systems, and improving water use efficiency in irrigated systems (where the natural resource base is not already constrained).

Plant protection. Tackling pests through an ecosystem approach that relies as much as possible on natural predation, other natural control mechanisms, diversity and resistance, with judicious use of pesticides, i.e. integrated pest management.

Agro-ecological approaches can also be used to increase the resilience of livestock systems. Pastures occupy approximately 3.5 billion hectares or 69 percent of total agricultural land, and the sector accounts for 40 percent of agricultural GDP. Degraded grasslands can be restored through better management practices - such as use of rotational grazing, the reintegration of crop and livestock activities or agroforestry systems - while animal productivity can be increased through better genetics and the application of better animal health systems and procedures (FAO, 2009b; FAO, 2011c).

Other opportunities include the integration of aquaculture with irrigated agriculture. For example, the integrated fish and rice fields in Laos are responsible for about 50 percent of all fish consumed by rural households and, at the same time, provide benefits such as pest management, weed control, maintenance of biodiversity and reduction or elimination of chemical pollutants (FAO/LARReC, 2007).

Diversification will be a key feature of resilient and sustainable production systems. Biodiversity serves as insurance against environmental changes by increasing the system's adaptive capacity. Agro-ecosystems that produce a diverse range of food types in an integrated way will be more resilient to pests, diseases and climatic fluctuations (Lin 2011; Perrings, 2006).

Dietary diversity is also essential for food and nutrition security. Initiatives aimed solely at increasing production and increasing energy intake will not reduce malnutrition as effectively as those that also recognize the importance of dietary quality and diversity. Foods sourced from animals, including fish, and legumes, fruits and vegetables are all important components of a nutritious diet. Thus, the agricultural sector can contribute to nutrition security by investing in small livestock and poultry ventures, sustainable aquaculture and horticulture, alongside staple crops. 
This will also help to diversify sources of income for farming households, another proven risk-reduction measure.

There are many synergies between the goals of environmental sustainability, food security and economic development - potentially "win-win-win" scenarios. For example, many options for agricultural mitigation of climate change, particularly those that involve soil carbon sequestration, also benefit adaptation, food security and development. Efforts to increase levels of soil organic matter translate into better plant nutrient content, increased water retention capacity and better structure, eventually leading to higher yields and greater resilience (FAO, 2009a).

Agriculture faces many challenges, not least coping with the rising demand for food, biofuel and other products by an increasing population combined with the demands for a more sustainable industry. Food security is key and requires the reconciliation of efficient production of food with reducing agriculture's environmental footprint.

So, the greening for management security of agribusiness corporation examines agriculture activities and their potential to impact both positively and negatively on the environment. The environmental management systems, environmental auditing, life cycle assessment and environmental impact assessment can be used for the greening for management security of agribusiness corporation.

Thorough reforms are needed to enable the effective greening of the greening for management security of agribusiness corporation:

Governance reforms that combine a national security and food security strategy are backed by sound plans to ensure the economic and social development of agribusiness in the context of global health and climate emergencies.

Fiscal reforms to make the private sector attractive for investment in green energy, low-carbon and sustainable infrastructure and services for agribusiness.

Financial reforms to provide sufficient income to invest in sustainable infrastructure, strengthen cooperation with state and local governments, and reform funding systems.

Reform of adult education to "arm" with new occupations and skills and specialty of system support of greening of economic security of agribusiness. Adult education as an important part of education system, to improve the overall quality, promotes economic development and social progress plays an extremely important role.

\section{References:}

1. https://ec.europa.eu/eurostat/statistics-explained/index.php?title=Agri-environmental_indicator__commitments

2. Daly H.E., Farley J. Ecological Economics: Principles and Applications: Island Press, 2010 - Secodition. $-539 \mathrm{p}$.

3. Ahmed M. Hussen Principles of environmental economics and sustainability: an integrated economic and ecological approach: London [u.a.]: Routledge, $2013-417$ p. 
4. Gasanov, Sergii and Petruha, Sergiy and Petruha, Nina, Consumer Behavior in a Mirror of Economic Security of Agribusiness (2014). Journal L' Association 1901 "SEPIKE", 2014, Available at SSRN: https://ssrn.com/abstract=3154395

5. Yatsiv, I. B. Complementary mechanism of state regulation of socio-economic protection of agricultural business / I. B. Yatsiv, T. I. Batrakova, A. V. Karabanov // Науковий вісник Полісся. - 2017. - № 2 (10). Ч. 1. - C. 166-171.

6. Bondarenko,O. and Sukhets'kyj, V. (2014). «Financial and economic security of the enterprise: theoretical and practical aspects». Efektyvna ekonomika. no. 10. URL: http://www.economy.nayka.com.ua/?op=1\&z=3580.

7. Harust, Yu. and Perelaznyj, A. (2015). «Financial and economic security of the agricultural enterprise: theoretical and legal aspects». Forum prava. no. 5. pp.39-44.

8. Davydiuk,T. V. (2013). «Financial and economic security or the financial component of economic security: an epistemological approach». Problemy teorii ta metodolohii bukhhalters'koho obliku, kontroliu i analizu. no. 1(25). pp.39-51.

9. Antoshkin,V. K. (2018). "Ways and principles of improving the financial and economic security of agricultural enterprises on the basis of a systematic approach». Molodyj vchenyj. no. 9 (61), pp.457-460.

10.Zhurakivs'kyj,Ye.S. (2015). «Conceptual principles for ensuring the economic security of the agricultural sector in the context of institutional transformations». Ahrosvit. no. 12. pp.63-70.

11.Utenkova,K. O. (2018). «Economic security of the agrarian sector: essence and functional components». Ahrosvit. no. 17, pp. 42-47.

12.http://www.fao.org/3/i2745e/i2745e00.pdf

13.http://sdi.wdc.org.ua/global

14. Sinyakevych IM Greening of forest use in the context of overcoming global environmental threats: a collective monograph. Lviv: Kamula, 2014. 592 p. 